\title{
PENGARUH DUA GAYA MENGAJAR MOSSTON DAN DUKUNGAN MOTOR ABILITY MAHASISWA TERHADAP HASIL BELAJAR TEKNIK DASAR SEPAK TAKRAW
}

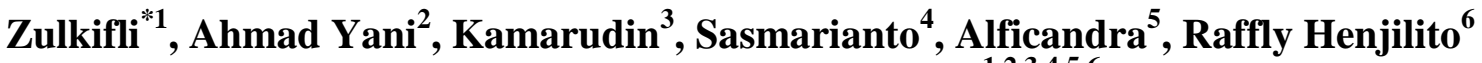 \\ Universitas Islam Riau, Indonesia ${ }^{1,2,3,4,5,6}$ \\ Email: zulkifli.darwis@edu.uir.ac.id ${ }^{* 1}$, ahmadyani.lc@gmail.com² ${ }^{2}$ Kamarudin@edu.uir.ac.id ${ }^{3}$, \\ sasmarianto@edu.uir.ac.id ${ }^{4}$, candraa@edu.uir.ac.id ${ }^{5}$,rafflyhenjilito@edu.uir.ac.id ${ }^{6}$
}

Received: 03 March 2020; Accepted 18 May 2020; Published 10 June 2020

Ed 2020; 5(1): 51-64

\begin{abstract}
ABSTRAK
Penelitian ini bertujuan untuk mengetahui pengaruh penerapan gaya mengajar latihan dan gaya mengajar inklusi pada kelompok mahasiswa yang memiliki motor ability tinggi dan rendah dalam proses pembelajaran teknik dasar sepak takraw. Metode penelitian ini menggunakan eksperimen faktorial $2 \times 2$ dengan treatment by level, populasi penelitian ini 82 orang mahasiswa program studi pendidikan jasmani Universitas Islam Riau yang terdaftar pada mata kuliah sepak takraw. Sampel berjumlah 44 orang dengan menggunakan teknik purposive sampling, terdiri dari 22 orang dengan motor ability tinggi dan 22 dengan motor ability rendah. Selanjutnya sampel dibagi ke dalam empat kelompok yang masing-masing berjumlah 11 orang. Teknik analisa data menggunakan anava dengan hasil uji lanjut t-dunnet, dengan hasil (1) Bagi mahasiswa yang memiliki motor ability tinggi, hasil belajar teknik dasar sepak takraw kelompok gaya mengajar latihan lebih baik dari gaya mengajar inklusi, dengan $\mathrm{t}_{0}=5,06 \geq \mathrm{t}_{\text {tabel }} 1,67$ maka $\mathrm{H}_{0}$ ditolak. (2) mahasiswa yang memiliki motor ability rendah, hasil belajar teknik dasar sepak takraw kelompok gaya mengajar inklusi lebih baik dari gaya mengajar latihan, dengan $t_{0}=-1,81 \leq \mathrm{t}_{\text {tabel }} 1,67$ maka $\mathrm{H}_{0}$ ditolak (3) Terdapat interaksi antara gaya mengajar dan motor ability terhadap hasil belajar teknik dasar sepak takraw, dengan $\mathrm{p}$-value $=0,000 \leq 0,05$ atau $\mathrm{H}_{0}$ ditolak.
\end{abstract}

Kata Kunci: Gaya Mengajar; Motor Ability; Hasil Belajar; Teknik Dasar; Sepak Takraw

\section{EFFECT OF TWO STYLE TEACHING MOSSTONS AND SUPPORT OF STUDENT MOTOR ABILITY ON LEARNING OUTCOMES OF SEPAK TAKRAW}

\begin{abstract}
This study aims to determine the effect of applying the teaching style of practice and inclusive teaching style on groups of students who have high and low motor abilities in the process of learning the basic techniques of sepak takraw. This research method uses experiments factorial $2 x 2$ with by level design, the population of this study was 82 students of physical education study programs at the Riau Islamic University. The sample of this study was 44 people taken using purposive sampling technique, consisting of 22 people with high motor ability and 22 people with low motor ability. Furthermore the sample was divided into four groups of 11 people each. The data analysis technique used ANAVA with the results of the t-dunnet advanced test. (1) For students who have a high motor ability, the results of the learning of the takraw basic techniques of teaching practice style groups are better than inclusi teaching styles, with $t_{0}=5.06 \geq t_{\text {table }} 1.67$ then $H_{0}$ is rejected. (2) Students who have low motor ability, the results of the learning of the basic techniques of takraw group inclusi teaching style is better than the teaching style of practice, with $t_{0}=-1.81 \leq t_{\text {table }} 1.67$ then $H_{0}$ is rejected. (3) There is an interaction between teaching style and motor ability on the results of the basic takraw learning techniques, with p-value $=0,000 \leq 0.05$ or $H_{0}$ rejected.
\end{abstract}

Keywords: Teaching Style; Motor Ability; The Learning Outcome; Basic Technique; Sepak Takraw 
Copyright (C) 2020, Journal Sport Area

DOI: https://doi.org/10.25299/sportarea.2020.vol5(1).4693

How To Cite: Zulkifli, Yani, A., Kamarudin., Sasmarianto., Alficandra., \& Henjilito, R. (2020). Pengaruh Dua Gaya Mengajar Mosston dan Dukungan Motor Ability Mahasiswa Terhadap Hasil Belajar Teknik Dasar Sepak Takraw. Journal Sport Area, 5(1), 51-64.

\section{PENDAHULUAN}

Mahasiswa yang terdaftar pada Program Studi Pendidikan Jasmani Kesehatan dan Rekreasi (Penjaskesrek) Universitas Islam Riau harus lulus semua mata kuliah, salah satunya adalah lulus pada mata kuliah sepak takraw dengan memiliki keterampilan dalam bermain sepak takraw. Seperti kita ketahui sepak takraw merupakan olahraga tradisional modern yang telah dimodifikasi dan diakui di seluruh dunia (Kosni, Abdullah, Juahir, Musa, Maliki, Rasid \& Eswaramoorthi, 2017). Sepak takraw dimainkan secara tim yang berjumlah tiga orang yang terdiri dari tekong, pengumpan dan spiker. Tekong bertanggung jawab atas layanan yang diambil, pengumpan melemparkan/melambungkan bola ke tekong sementara spiker bertanggung jawab atas spiking bola (Kosni et al. 2018). Adapun keterampilan yang dibutuhkan dari setiap pemain sepak takraw meliputi keterampilan individu: sepak sila, sepak kuda, sepak petik, sepak badik, sepak cangkuk, menggunakan paha dan menyundul bola (heading). dan keterampilan penguasaan pertandingan meliputi: sepak mula, timangan, memberi umpan (passing), melakukan smes dan melakukan block (Hanif, 2015).

Dari observasi yang telah peneliti lakukan di lapangan, masih banyak dari mahasiswa Penjaskesrek Universitas Islam Riau angkatan tahun 2016 setelah lulus mata kuliah sepak takraw dasar pada semester 3 (tiga) belum memiliki kemampuan dan keterampilan yang diharapkan dalam bermain sepak takraw. Hasil wawancara dengan dosen pengampu mata kuliah sepak takraw menyebutkan bahwa dosen dalam mengajar telah menggunakan perangkat pembelajaran dan hal penting lainnya sebagai upaya untuk mencapai tujuan pembelajaran, tetapi perolehan nilai hasil belajar mata kuliah sepak takraw mahasiswa belum memuaskan. Dari hasil observasi dan wawancara tersebut peneliti berasumsi ada beberapa faktor yang mempengaruhi hasil belajar mata kuliah sepak takraw kurang memuaskan dan belum memperoleh hasil maksimal, antara lain disebabkan oleh waktu belajar yang terbatas, jumlah satuan kredit semester yang relatif kecil (2 SKS), fasilitas yang kurang memadai, gaya mengajar yang digunakan dosen pengampu kurang efektif, adanya perbedaan kemampuan gerak (motor ability) pada mahasiswa, kurangnya motivasi dan bakat yang dimiliki oleh setiap mahasiswa.

Berbagai kemungkinan di atas dipandang perlu mencari penyebabnya, salah satunya untuk meningkatkan penguasaan teknik dasar sepak takraw melalui penggunaan gaya mengajar dalam pembelajaran pendidikan jasmani, yang mana Jaakkola dan Anthony (2011) menyatakan bahwa spectrum gaya mengajar pendidikan jasmani sudah dikenal luas dan digunakan oleh Guru Pendidikan Jasmani sebagai kerangka kerja pengajaran untuk mengajar pendidikan jasmani. Adapun gaya mengajar dalam pendidikan jasmani ini dikenal dengan gaya mengajar Mosston yang terdiri dari 11 gaya mengajar antara lain gaya mengajar command (style a), practice (style b), reciprocal (style c), self-check (style d), inclusion (style e), guided discovery (style f), convergent discovery(style g), divergent discovery (style h), learner-designed (style i), learnerinitiated (style j), self-teaching (style k) (Byra, 2018). Penggunaan dari setiap gaya Mosston dalam pendidikan jasmani masing-masing mempunyai tujuan dan juga bisa memotivasi siswa dalam belajar, hasil penelitian dari Fernández-Rivas dan Espada- 
Mateos (2019) menyatakan penggunaan gaya mengajar yang berbeda sangat penting ketika memberikan kelas pendidikan jasmani berdasarkan tujuan latihan. Penelitian lainnya dari Hein, Ries, Pires, Caune, Emeljanovas, Ekler, dan Valantiniene, (2012) menyatakan bahwa penggunaan setiap gaya tergantung pada tujuan pengajaran yang ingin dicapai dalam pendidikan jasmani dan terbukti memotivasi siswa untuk aktif secara fisik bahkan setelah lulus sekolah. Adapun penggunaan gaya mengajar Mosston oleh Guru Pendidikan Jasmani di Indonesia hasil dari beberapa penelitian menyatakan bahwa Guru Pendidikan Jasmani belum menerapkan secara utuh gaya mengajar berdasarkan konsep dari Mosston (Setiawan \& Nopembri, 2013) dan Guru Pendidikan Jasmani belum mengetahui gaya mengajar yang sesuai (Prasetyo, 2013).

Hasil penelitian berkaitan meningkatkan hasil belajar sepak takraw telah dilakukan menggunakan beberapa pendekatan, antara lain penelitian dari Sigit (2014) menyatakan bahwa dengan menggunakan pendekatan permainan krawnis dapat meningkatkan hasil belajar sepaktakraw. Penelitian Arman, Sulaiman, dan Rustiadi (2013) menyatakan bahwa permainan sepak takraw asik dapat meingkatkan pembelajaran dalam sepak takraw. Penelitian Widodo dan Sudarso (2018) menyebutkan bahwa ada peningkatkan sebesar $18,34 \%$ dalam pembelajaran sepak sila dengan pendekatan modifikasi permainan. penelitian dari Saputra, Yarmani, Sugihartono, dan Deflianto (2018) menyatakan bahwa ada peningkatkan pembelajaran sepak mula bawah setelah menggunakan bola karet yang dimodifikasi. Temuan-temuan dari penelitian tersebut di atas tidak dilakukan pada keseluruhan teknik dasar sepak takraw, cuma pada salah satu teknik dasar sepak takraw dan sampelnya adalah siswa sekolah dasar dan siswa Sekolah Menengah Pertama. Upaya lainnya berkaitan dengan penggunaan gaya mengajar untuk meningkatkan hasil belajar sepak sila bagi mahasiswa yang memiliki kemampuan motorik tinggi lebih baik diajar dengan gaya mengajar resiprokal dan bagi mahasiswa yang motorik rendah lebih baik diajar dengan gaya mengajar latihan (Suprayitno, 2018). Dari penelitian ini terdapat dua gaya mengajar yang berbeda, yang pertama gaya mengajar resiprokal dengan belajar secara berpasangan dan yang kedua gaya mengajar latihan dengan belajar secara individu. Dari penelitian ini belum bisa menjawab gaya mengajar mana yang lebih baik kalau materi/kontennya tentang teknik dasar sepak takraw lainnya? dan untuk karakteristik gaya mengajar mahasiswa secara individual, mana yang lebih baik gaya mengajar latihan atau gaya mengajar inklusi? oleh sebab itu perlu kiranya dilakukan suatu penelitian yang nanti hasilnya akan memudahkan para guru untuk menggunakan gaya mengajar yang sesuai.

Kebaharuan dari penelitian ini meneliti tentang gaya mengajar latihan (B) dan gaya mengajar Inklusi (E). Dua gaya mengajar yang karakteristiknya mahasiswa sama-sama belajar secara individual, perbedaannya pada proses pelaksanaan dan pengambilan keputusan. Gaya mengajar latihan siswa belajar secara individu dengan melakukan tugas dari yang dicontohkan guru (Mosston \& Ashworth, 2008), sedangkan gaya mengajar inklusi siswa belajar secara individu dengan memilih untuk memulai belajar dari tingkat kesulitan yang telah ditetapkan dan dibuat guru (Mosston \& Ashworth, 2008). Penelitian ini juga menjawab tentang hasil belajar teknik dasar dan lanjutan sepak takraw (sepak sila, heading/sundulan, sepak mula/service dan smash) dari penggunaan dua gaya mengajar ini.

Selain dari gaya mengajar, peran siswa dalam proses belajar teknik dasar sepak takraw memerlukan kesiapan fisik yang baik. Harsono (2015) menyatakan kesiapan fisik yang tidak cukup akan pula memperlambat atau membatasi kemajuan dalam 
mempelajari teknik, kesiapan fisik di sini berfokus kepada motor ability yang dimiliki siswa. Ability atau general motor ability didefinisikan sebagai kapasitas yang diwariskan dan dipelajari yang ditunjukkan dalam kinerja kegiatan keterampilan dasar (Battineli, 2007). Adapun komponen motor ability dijelasakan lanjut oleh Battineli (2007) yaitu kekuatan otot, daya tahan otot, kekuatan, kecepatan, daya tahan kardiovaskular, fleksibility, kelincahan dan koordinasi. Bagi mahasiswa yang akan belajar rangkaian gerak teknik dasar sepak takraw menggunakan dua gaya mengajar yang telah ditentukan pada penelitian ini, tentu akan memiliki pengalaman belajar dalam gerak yang berbeda, ada yang belajar mengikuti rangkaian tugas gerak teknik dasar secara keseluruhan berdasarkan dari contoh gerakan yang telah diperagakan oleh guru dan ada yang pengalaman belajar teknik dasar sepak takraw berdasarkan dari gerakan yang sudah disusun tingkat kesulitannya dari yang termudah ke yang sulit. Dari bentuk pengalaman belajar ini, bagaimanakah peran motor ability yang dimiliki oleh mahasiswa akan mendukung untuk memperoleh hasil belajar teknik dasar sepak takraw yang lebih baik, karena salah satu alasan penyebab seseorang melakukan kesalahan dalam belajar keterampilan gerak adalah karna kurangnya kemampuan motorik (Čoh, Golubović, \& Bratić, 2004).

Meskipun motor ability mendukung dalam proses belajar dalam olahraga dan spektrum gaya mengajar dari Mosston menyediakan berbagai pilihan pembelajaran dan kerangka teoritis yang sangat baik. Tetapi keterkaitan dan gabungan dari gaya mengajar latihan, inklusi dan motor ability tinggi dan rendah yang dimiliki oleh mahasiswa untuk memiliki hasil belajar teknik dasar sepak takraw yang baik belum terjawab. Oleh karena itu, tujuan dari penelitian ini adalah untuk menguji apakah ada perbedaan dalam hasil belajar yang diajarkan oleh gaya mengajar latihan, inklusi dan motor ability pada mahasiswa program studi pendidikan jasmani Universitas Islam Riau yang terdaftar pada kelas mata kuliah sepak takraw.

\section{METODE PENELITIAN}

Penelitian ini menggunakan metode eksperimen. Menurut Sugiyono (2011) metode eksperimen digunakan untuk mencari pengaruh treatment (perlakuan) tertentu terhadap yang lain dalam kondisi yang terkendalikan. Desain yang digunakan eksperiment factorial $2 \times 2$ dengan treatment by levels. Penelitian ini terdiri dari variabel bebas, variabel moderator dan variabel terikat. Variabel bebas yaitu gaya megajar, variabel moderator yaitu motor ability sedangkan variabel terikatnya dalah hasil belajar teknik dasar sepak takraw. Variabel perlakuan terdiri dari dua gaya mengajar, yaitu gaya mengajar latihan $\left(A_{1}\right)$ dan gaya mengajar inklusi $\left(A_{2}\right)$. Variabel yang mempengaruhi yaitu motor ability tunggi $\left(\mathrm{B}_{1}\right)$ dan motor ability rendah $\left(\mathrm{B}_{2}\right)$.

Populasi pada penelitian ini adalah mahasiswa Penjaskesrek Universitas Islam Riau yang terdaftar pada mata kuliah sepak takraw yang berjumlah 82 orang. Teknik pengambilan sampel menggunakan teknik purposive sampling yaitu penentuan sampel dengan pertimbangan karakteristik tertentu (Syah, 2010), yang mana seluruh populasi diukur tingkat motor ability dengan menggunakan barrow motor ability tes dengan tes yang sudah baku dengan reliabilitas 0,98 (Standing broad jump, soft ball throw, zig-zag run, wall pass, medicine ball put, lari cepat 50 meter) (Morrow-Jr, Mood, Disch, \& Kang, 2015). Berdasarkan skor dari hasil pengukuran kemudian dihitung T-skornya selanjutnya di ranking dan pengelompokan sampel menggunakan rumus Verducci (1989) yaitu menseleksi $27 \%$ jumlah data skor tertinggi dan $27 \%$ skor terendah. 
Selanjutnya, 27\% dari jumlah skor data tertinggi digolongkan dalam kelompok yang memiliki motor ability tinggi (B1), sedangkan 27\% dari jumlah skor terendah digolongkan dalam kelompok yang memiliki motor ability rendah (B2) dari masingmasing kelompok. Dari perhitungan tersebut didapatkan $27 \%$ dari tiap-tiap kelompok untuk skor tertinggi dan terendah pada sampel adalah $27 \%$ x $82=22$ orang. Hasilnya didapatkan sampel berjumlah 44 orang yang terbagi kedalam 22 orang yang memiliki motor ability tinggi dan 22 orang yang memiliki motor ability rendah. Selanjutnya pengelompokan dibagi ke dalam dua kelompok dengan acak sederhana kedalam masing-masing kelompok, yaitu (1) kelompok mahasiswa yang diberi gaya mengajar latihan yang memiliki motor ability tinggi $\left(\mathrm{A}_{2} \mathrm{~B}_{1}\right)$ berjumlah 11 orang. (2) kelompok mahasiswa yang diberi gaya mengajar inklusi yang memiliki motor ability tinggi $\left(\mathrm{A}_{3} \mathrm{~B}_{1}\right)$ berjumlah 11 orang. (3) kelompok mahasiswa yang diberi gaya mengajar latihan yang memiliki motor ability rendah $\left(\mathrm{A}_{2} \mathrm{~B}_{1}\right)$ berjumlah 11 orang. (4) kelompok mahasiswa yang diberi gaya mengajar inklusi yang memiliki motor ability rendah $\left(\mathrm{A}_{3} \mathrm{~B}_{2}\right)$ berjumlah 11 orang. Matrik pengelompokan sampel eksperimen dapat dilihat pada tabel 1:

Tabel 1. Desain Penelitian

\begin{tabular}{ccc}
\hline Gaya Mengajar & \multicolumn{2}{c}{ Gaya Mengajar } \\
\cline { 2 - 3 } Motor Ability & Latihan $\left(\mathrm{A}_{\mathbf{1}}\right)$ & Inklusi $\left(\mathrm{A}_{\mathbf{2}}\right)$ \\
\hline Motor Ability Tinggi $\left(\mathrm{B}_{1}\right)$ & $\mathrm{A}_{1} \mathrm{~B}_{1}(11$ Orang $)$ & $\mathrm{A}_{2} \mathrm{~B}_{1}$ ( 11 Orang) \\
\hline Motor Ability Rendah $\left(\mathrm{B}_{2}\right)$ & $\mathrm{A}_{1} \mathrm{~B}_{2}(11$ Orang) & $\mathrm{A}_{2} \mathrm{~B}_{2}$ (11 Orang) \\
\hline
\end{tabular}

Penelitian ini dibantu oleh dua orang staf pengajar di lingkungan Universitas Islam Riau yang terlebih dahulu telah setuju dan bersedia untuk membentu dalam penelitian ini. banyaknya perlakuan pada penelitian ini 16 kali perlakuan dengan waktu 2 x 50 menit setiap satu kali perlakuan (Helaprahara, 2017). Pada setiap kelompok diajar dengan gaya mengajar latihan dan gaya mengajar inklusi sesuai konsep dari gaya mengajar Mosston dan Ashwortd dengan materi pembelajaran teknik dasar sepak takraw (sepak sila, heading/sundulan, sepak mula/service dan smash).

Penelitian ini dilaksanakan di lapangan sepak takraw FKIP Universitas Islam Riau dari tanggal 17 April - 22 Mei 2017, validitas internal dan eksternal pada penelitian ini terkontrol dengan baik. Setelah selesai perlakuan pada penelitian untuk memperoleh data hasil belajar teknik dasar sepak takraw menggunakan instrumen tes yang sudah diuji cobakan pada sampel yang berbeda dan sudah divalidasi oleh para ahli sepak takraw dengan reliabilitas (sepak sila 0,71. heading/sundulan 0,76. sepak mula/service 0,73. smash 0,72 ) dengan artian bahwa tes ini layak untuk digunakan untuk mengukur hasil belajar teknik dasar sepak takraw.

Pengujian hipotesis pada penelitian ini dilakukan dengan menggunakan analysis of variance (ANAVA), sebelum dilakukan analisis maka terlebih dahulu akan dilakukan uji normalitas data menggunakan teknik uji Lilliefors. Dengan kriteria jika hasil pengujian menujukkan bahwa $\mathrm{L}_{\text {hitung }}<\mathrm{L}_{\text {tabel}}$, maka data berasal dari populasi yang berdistribusi normal (Kadir, 2010). Pengujian hipotesis menggunakan taraf signifikansi $\alpha=0,05$. Uji homogenitas tiap kelompok menggunakan uji $F_{\text {maks }}$ Hertley yang mana E.T. Ruseffendi dalam Kadir (2015) mengatakan bahwa uji homogen ini sama dengan uji bartlett. Dengan kriteria, jika hasil pengujian menunjukkan $\mathrm{F}_{\text {hitung }}<\mathrm{F}_{\text {tabel }}$, maka data tersebut memiliki varian yang sama atau homogen. Pengujian hipotesis menggunakan taraf signifikansi $\alpha=0,05$. 
Uji normalitas dan uji homogenitas telah dilaksanakan selanjutnya baru dilakukan pengujian hipotesis penelitian dengan menggunakan analisis anava. Apabila hasil analisis varians menunjukkan adanya pengaruh utama (main effect) antara variabel bebas terhadap variabel terikat dan adanya interaksi (simple effect) variabel bebas terhadap variabel terikat maka dilanjutkan dengan uji dunnet sebagai uji lanjut untuk menentukan kelompok mana yang memiliki hasil belajar yang lebih baik yang dilakukan pada taraf signifikansi $\alpha=0,05$.

\section{HASIL DAN PEMBAHASAN}

Statistik deskriptif dihitung untuk skor rata-rata dan standar deviasi dari dua kelompok perlakukan: 2 (motor ability) x 2 (gaya mengajar) analisis kelompok independen (ANOVA) digunakan untuk memeriksa apakah ada perbedaan signifikan antara gaya mengajar dan motor ability. Nilai rata-rata dan standar deviasi hasil belajar teknik dasar sepak takraw untuk motor ability tinggi dan motor ability rendah pada dua kelompok gaya mengajar dijelasakan pada tabel 2:

Tabel 2. Deskripsi Data

\begin{tabular}{cccc}
\hline Kelompok & $\boldsymbol{N}$ & $\boldsymbol{M}$ & $\boldsymbol{S D}$ \\
\hline $\mathrm{A}_{1} \mathrm{~B}_{1}$ & 11 & 51.99 & 4.34 \\
$\mathrm{~A}_{2} \mathrm{~B}_{1}$ & 11 & 42.72 & 4.08 \\
$\mathrm{~A}_{1} \mathrm{~B}_{2}$ & 11 & 47.87 & 3.85 \\
$\mathrm{~A}_{2} \mathrm{~B}_{1}$ & 11 & 51.18 & 4.82 \\
\hline
\end{tabular}

Keterangan : $M=$ Mean

$S D=$ Standard Deviation

Untuk melihat apakah data yang diperoleh dari masing-masing variabel penelitian normal atau tidak, maka dilakukan uji normalitas dengan menggunakan Uji Liliefors. Apabila hasil dari harga $\mathrm{L}_{\text {hitung }}\left(\mathrm{L}_{0}\right)$ tertinggi dari kelompok variabel yang diteliti lebih kecil dari pada $\mathrm{L}_{\text {tabel }}\left(\mathrm{L}_{\mathrm{t}}\right)$ dalam daftar tabel liliefors, maka data tersebut dikatakan berdistribusi normal. Sedangkan yang dimaksud dengan $\mathrm{L}_{\text {hitung }}\left(\mathrm{L}_{0}\right)$ adalah selisih antara harga mutlak terbesar antara peluang data mentah dengan proposi data mentah. Untuk lebih jelasnya akan disajikan hasil perhitungan normalitas dari variabel yang diteliti dengan menggunakan uji liliefors pada taraf signifikansi a $=0,05$.

Tabel 3. Hasil Uji Coba Normalitas

\begin{tabular}{cccccc}
\hline No & \multicolumn{1}{c}{ Kelompok } & $\mathbf{N}$ & $\mathbf{L}_{\text {hitung }}$ & $\mathbf{L}_{\text {tabel }}$ & Keterangan \\
\hline 1 & Kelompok $\mathrm{A}_{1} \mathrm{~B}_{1}$ & 11 & 0,084 & 0,249 & Normal \\
\hline 2 & Kelompok $\mathrm{A}_{2} \mathrm{~B}_{1}$ & 11 & 0,170 & 0,249 & Normal \\
\hline 3 & Kelompok $\mathrm{A}_{1} \mathrm{~B}_{2}$ & 11 & 0,121 & 0,249 & Normal \\
\hline 4 & Kleompok $\mathrm{A}_{2} \mathrm{~B}_{2}$ & 11 & 0,126 & 0,249 & Normal \\
\hline
\end{tabular}

Uji homogenitas dilakukan terhadap data skor hasil belajar teknik dasar sepak takraw pada masing-masing kelompok yang akan dilakukan pencarian dengan menggunakan anava. 
Zulkifli, Ahmad Yani, Kamarudin, Sasmarianto, Alficandra dan Raffly Henjilito (2020) Pengaruh Dua Gaya Mengajar Mosston dan Dukungan Motor Ability Mahasiswa Terhadap Hasil Belajar Teknik Dasar Sepak Takraw

Tabel 4. Hasil Uji Homogenitas

Levene's Test of Equality of Error Variances ${ }^{\mathrm{a}}$

Dependent Variable: Skor Hasil Belajar

\begin{tabular}{cccc}
\hline F & df1 & df2 & Sig. \\
\hline .424 & 3 & 40 & .737 \\
\hline
\end{tabular}

Dari hasil analisis pada tabel Lavena's Test of Equality of error Variances, diperoleh $\mathrm{F}=0,4245 ; \mathrm{db} 1=3 ; \mathrm{db} 2=40$, dan $\mathrm{p}$-value $=0,7379>0,05$ atau $\mathrm{H}_{0}$ diterima. Dengan demikian, secara keseluruhan data kelompok hasil belajar teknik dasar sepak takraw homogen. Setelah uji prasyarat terpenuhi dilanjutkan dengan pengujian hipotesis dengan mengunakan analisis varian dua jalur untuk mengetahui perbedaan hasil belajar teknik dasar sepak takraw dari dua gaya mengajar yang berbedaan.

Tabel 5. Analisis Deskriptif Statistik Gaya Mengajar dengan Motor Ability

\begin{tabular}{lccccc}
\hline \multicolumn{1}{c}{ Source } & $\begin{array}{c}\text { Type III Sum } \\
\text { of Squares }\end{array}$ & Df & Mean Square & F & Sig. \\
\hline Corrected Model & $583.626^{\mathrm{a}}$ & 3 & 194.542 & 10.58 & 0 \\
\hline Intercept & 103242.1 & 1 & 103242.1 & 5614.91 & 0 \\
\hline $\mathrm{A}$ & 97.119 & 1 & 97.119 & 5.282 & 0.027 \\
\hline $\mathrm{B}$ & 51.993 & 1 & 51.993 & 2.828 & 0.1 \\
\hline $\mathrm{A} * \mathrm{~B}$ & 434.513 & 1 & 434.513 & 23.631 & 0 \\
\hline Error & 735.485 & 40 & 18.387 & & \\
\hline Total & 104561.2 & 44 & & & \\
\hline Corrected Total & 1319.111 & 43 & & & \\
\hline
\end{tabular}

Hasilnya diperoleh Fo $(\mathrm{A})=5.282$ dengan p-value $=0,027 \leq 0,05$ atau $\mathrm{H}_{0}$ ditolak. $\mathrm{Hal}$ ini berarti terdapat perbedaan rata-rata hasil belajar teknik dasar sepak takraw antara mahasiswa yang diajar dengan gaya mengajar latihan dan gaya mengajar inklusi, sementara Fo $(B)=2.828$ dengan $\mathrm{p}$-value $=0,100 \leq 0,05$ atau $\mathrm{H}_{0}$ diterima. Hal ini berarti tidak terdapat perbedaan rata-rata hasil belajar teknik dasar sepak takraw mahasiswa yang memiliki motor ability tinggi dan mahasiswa yang memilki motor ability rendah. Selanjutnya $\mathrm{Fo}(\mathrm{AB})=23.631$ dengan $\mathrm{p}$-value $=0,000 \leq 0,05$ atau $\mathrm{H}_{0}$ ditolak. Hal ini berarti ada pengaruh interaksi yang signifikan antar faktor A (gaya mengajar ) dan faktor B (motor ability) terhadap hasil belajar teknik dasar sepak takraw

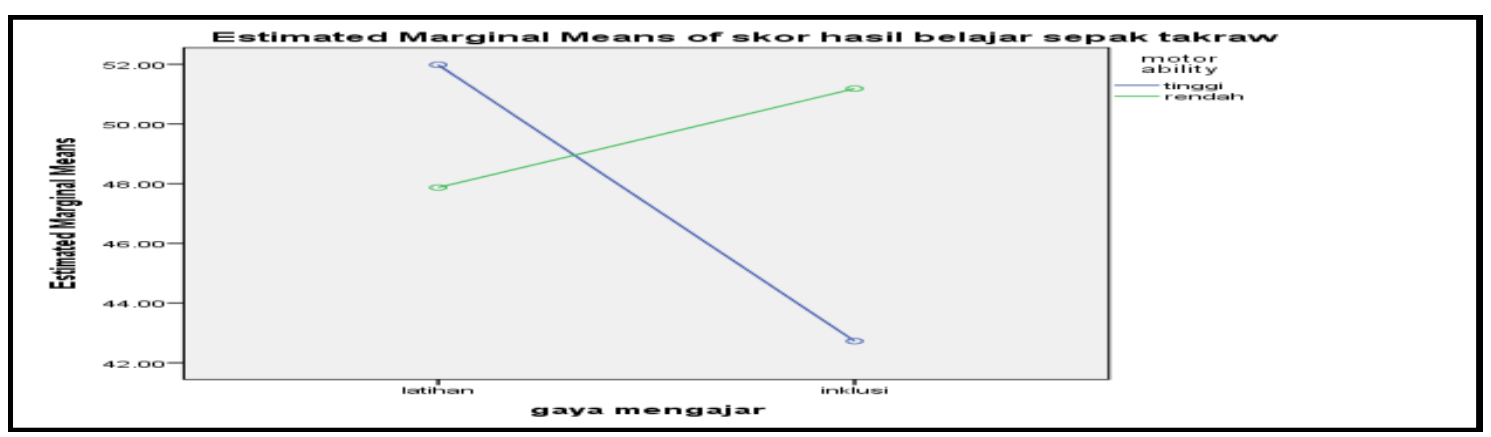

Gambar 1. Interaksi $A^{*} B$ 
Tabel 6. Hasil Uji lanjut dengan t-dunnet

\begin{tabular}{ccccccc}
\hline No & \multicolumn{1}{c}{ Nilai kontras } & $(\mathbf{S e})$ & $\mathbf{t}_{\mathbf{0}}$ & $\mathbf{t}_{\text {tabel }}$ & Ket \\
\hline 1 & $\overline{\mathrm{Y}}_{\mathrm{A} 1 \mathrm{~B} 1}-\overline{\mathrm{Y}}_{\mathrm{A} 2 \mathrm{~B} 1}(51,98-42,72)=9,26$ & 1,09 & 5,06 & 1,67 & Signifikan \\
\hline 2 & $\overline{\mathrm{Y}}_{\mathrm{A} 1 \mathrm{~B} 2}-\overline{\mathrm{Y}}_{\mathrm{A} 2 \mathrm{~B} 2}(47,87-51,18)$ & $=-3,31$ & 1,09 & $-1,81$ & 1,67 & Signifikan \\
\hline
\end{tabular}

Hasinya diperoleh, (1) $\overline{\mathrm{Y}}_{\mathrm{A} 1 \mathrm{~B} 1}-\overline{\mathrm{Y}}_{\mathrm{A} 2 \mathrm{~B} 1}$ dengan $\mathrm{t}_{0}=5,06 \geq \mathrm{t}_{\text {tabel }} 1,67$ maka $\mathrm{H}_{0}$ ditolak. Dengan demikian rata-rata hasil belajar teknik dasar sepak takraw kelompok gaya mengajar latihan lebih tinggi daripada kelompok gaya mengajar inklusi untuk mahasiswa yang memiliki motor ability tinggi. (2) $\overline{\mathrm{Y}}_{\mathrm{A} 1 \mathrm{~B} 2}-\overline{\mathrm{Y}}_{\mathrm{A} 2 \mathrm{~B} 2}$ dengan $\mathrm{t}_{0}=-1,81 \leq$ $\mathrm{t}_{\text {tabel }}$ 1,67 maka $\mathrm{H}_{0}$ ditolak. Dengan demikian rata-rata nilai hasil belajar teknik dasar sepak takraw kelompok gaya mengajar latihan lebih rendah daripada kelompok gaya mengajar inklusi untuk mahasiswa yang memiliki motor ability rendah.

\section{Terdapat Perbedaan Pengaruh Antara Gaya Mengajar Latihan dengan Gaya Mengajar Inklusi Terhadap Hasil Belajar Teknik Dasar Sepak Takraw Mahasiswa Penjaskesrek Universitas Islam Riau Pada Kelompok Mahasiswa Yang Memiliki Motor Ability Tinggi}

Pada kontras nilai kedua kelompok perlakuan $\overline{\mathrm{Y}}_{\mathrm{A} 1 \mathrm{~B} 1}-\overline{\mathrm{Y}}_{\mathrm{A} 2 \mathrm{~B} 1}$ dengan $\mathrm{t}_{0}=5,06 \geq$ $\mathrm{t}_{\text {tabel }}$ 1,67 maka $\mathrm{H}_{0}$ ditolak. Dengan demikian menunjukkan bahwa nilai hasil belajar teknik dasar sepak takraw kelompok gaya mengajar latihan pada mahasiswa yang memiliki motor ability tinggi lebih tinggi nilainya daripada kelompok gaya mengajar inklusi yang juga memiliki motor ability tinggi. Artinya, bahwa gaya mengajar latihan untuk mahasiswa yang memiliki motor ability tinggi pengaruhnya lebih baik dari gaya mengajar inklusi. Pada gaya mengajar latihan tugas gerak diberikan secara keseluruhan dari awal sampai akhir gerakan, yang mana mahasiswa harus melakukan gerakan yang sudah diinstruksikan oleh dosen, baik itu gerakan yang sulit atau yang mudah, merupakan menjadi satu kesatuan sisitimatis yang harus dipelajari. Disini mahasiswa belajar gerak dari tahap kognitif, asosiatif dan sampai pada otomatisasi. Karena ini dilakukan pada mahasiswa yang memiliki motor ability tinggi akan mudah dalam melakukan rangkain tugas gerak dari awal sampai akhir dari tugas gerak dan waktuwaktu yang tersedia akan menjadi sangat efektif karena memiliki kesempatan untuk melakukan banyak pengulangan. Chatoupis dan Vagenas (2018) menyatakan bahwa gaya latihan sangat ideal untuk mempelajari tugas spesifik yang ada, karena jumlah waktu latihan maksimum yang disediakan oleh gaya ini.

Pada kelompok gaya mengajar inklusi mahasiswa diberi kebebasan untuk memilih suatu tingkatan tugas untuk dapat melaksanakan dan menawarkan suatu tantangan untuk memeriksa hasil kerjanya. Intinya, tugas yang sama dirancang untuk derajat tingkat kesulitan yang berbeda. Di sini belajar bukan pada proses gerakan, tetapi lebih pada hasil akhir dari gerakan yang dihasilkan dari tingkat kesulitan yang sudah dibuat oleh dosen sebelumnya. Untuk itu poin penting pada gaya inklusi ini mahasiswa harus cepat menguasai tingkat kesulitan dan memutuskan untuk dapat menaikkan status mereka ke dalam tugas yang lebih tinggi tingkat kesukarannya. Untuk mahasiswa yang memiliki motor ability tinggi pada gaya mengajar inklusi ini akan memudahkan dalam menguasai tingkat kesulitan, tetapi di sini keberanian untuk naik pada tingkat kesulitan selanjutnya tiap mahasiswa berbeda-beda, sehingga pada kelompok ini membutuhkan waktu yang lebih lama untuk mengusai teknik dasar sepak takraw yang baik jika dibandingkan dengan kelompok gaya mengajar latihan yang sama-sama memiliki motor ability tinggi. 
Temuan yang sama juga dinyatakan oleh Byra, Sanchez dan Wallhead (2014) ketika menggunakan gaya inklusi guru mengajar harus menyadari bahwa siswa akan menghabiskan lebih banyak waktu dalam pengajaran dan pengetahuan pasif selama waktu kegiatan karena guru harus memodelkan berbagai tingkat kesulitan tugas kepada siswa dan siswa harus membuat keputusan tentang pemilihan tingkat kesulitan tugas saat melakukan aktivitas.

\section{Terdapat Perbedaan Pengaruh Antara Gaya Mengajar Latihan dengan Gaya Mengajar Inklusi Terhadap Hasil Belajar Teknik Dasar Sepak Takraw Mahasiswa Penjaskesrek Universitas Islam Riau Pada Kelompok Mahasiswa Yang Memiliki Motor Ability Tinggi}

Pada kontras nilai kedua kelompok perlakuan $\overline{\mathrm{Y}}_{\mathrm{A} 1 \mathrm{~B} 2}-\overline{\mathrm{Y}}_{\mathrm{A} 2 \mathrm{~B} 2}$ dengan $\mathrm{t}_{0}=-1,81 \leq$ $\mathrm{t}_{\text {tabel }}$ 1,67 maka $\mathrm{H}_{0}$ ditolak. Hasil hipotesis kedua menunjukkan bahwa nilai hasil belajar teknik dasar sepak takraw kelompok gaya mengajar latihan pada mahasiswa yang memiliki motor ability rendah lebih rendah nilainya daripada kelompok gaya mengajar inklusi yang juga memiliki motor ability rendah. Artinya, bahwa gaya mengajar inklusi untuk mahasiswa yang memiliki motor ability rendah pengaruhnya lebih baik dari gaya mengajar latihan. Gaya mengajar latihan pada pelaksanaannya mengulang-mengulang gerakan yang sudah didemontrasikan oleh dosen supaya mahasiswa bisa menguasai gerakan dari teknik dasar sepak takraw, dari fase awal gerakan sampai fase akhir dari macam gerakan teknik dasar sepaktakraw. Dari setiap gerakan saling berkesinambungan membentuk suatu teknik dasar yang dipelajari. Bagi mahasiswa yang memiliki motor ability rendah tentunya mempunyai banyak kesempatan untuk mengulang-ulang gerakan dengan harapan bisa menguasai teknik dasar sepak takraw yang dipelajari, tetapi pengulangan yang dilakukan dengan motor ability rendah yang mereka miliki membuat mereka kurang baik dalam melakukan rangkaian gerakan. Untuk siswa yang memiliki kemampuan rendah dalam proses belajar kurang potensial dalam memperoleh keterampilan motorik yang kompleks (Puspitorini \& Tangkudung, 2016). Pada kelompok ini kebanyakan dari mereka menjadi lemas karena banyak menguras tenaga dan pikiran. Thomson (2010) menyatakan bahwa gaya mengajar latihan merupakan gaya mengajar "klasik", yang mana pada gaya mengajar ini siswa bisa memiliki lebih banyak melakukan aktivitas dengan kecepatan yang mereka pilih sendiri, tentunya pengeluaran energi lebih banyak terjadi.

Pada gaya mengajar inklusi materi teknik dasar sepak takraw oleh dosen menyiapkan materi dengan beberapa kriteria tingkat kesulitan, mahasiswa bisa memilih dari mana dia harus mulai belajar. Kedua gaya mengajar ini jika diberikan kepada mahasiswa dengan motor ability rendah, mahasiswa bisa belajar dari tingkat gerakan yang mudah dan sederhana dengan harapan belajar dari tingkat kesulitan masing-masing dan akan lebih termotivasi untuk belajar dan menyelesaikan tugas yang diberikan. Motor ability yang rendah dan penggunaan waktu yang maksimal akan membuat kelompok ini lebih memiliki hasil yang baik. Chatoupis (2005) menyebutkan bahwa anak-anak yang menganggap diri mereka kompeten pada keterampilan akan mempertahankan minat dalam menguasai keterampilan dan terlibat di dalamnya, memilih gaya mengajar Inklusi masuk akal. 


\section{Terdapat Interaksi Antara Gaya Mengajar dan Motor Ability Terhadap Hasil Belajar Teknik Dasar Sepaktakraw Mahasiswa Penjaskesrek Universitas Islam Riau}

Berdasarkan hasil analisis data penelitian, dinyatakan bahwa adanya interaksi antara gaya mengajar (A) dengan motor ability (B) pada nilai pengujian Interaksi kedua kelompok $(\mathrm{AxB})$ terdapat harga nilai $\mathrm{Fo}(\mathrm{AB})=23.631$ dengan $\mathrm{p}$-value $=0,000 \leq 0,05$ atau $\mathrm{H}_{0}$ ditolak. Hal ini berarti ada pengaruh interaksi yang sangat signifikan antar faktor A (gaya mengajar) dan faktor B (motor ability) terhadap hasil belajar teknik dasar sepak takraw pada mahasiswa Penjaskesrek FKIP Universitas Islam Riau. Penguasaan teknik dasar sepak takraw diajarkan melalui berbagai macam gaya mengajar, tentunya di setiap gaya mengajar memiliki aktifitas dan cara yang berbeda dalam proses pembelajaran. Seperti gaya mengajar latihan yang bersifat diulang-ulang, gaya mengajar inklusi yang mahasiswa belajar dari memilih rangkaian tugas yang mudah dari yang sulit. Kesemua hal tersebut tentunya akan didukung juga oleh motor ability yang dimiliki oleh setiap mahasisiwa, yang mana di sini pengelompokan mahasiswa berdasarkan pada motor ability tinggi dan motor ability rendah yang akan mendukung dalam setiap gaya mengajar yang digunakan pada mahasisiwa dalam proses pembelajaran. Tentunya dengan memiliki motor ability yang berbeda-beda akan mempengaruhi hasil yang berbeda pula terhadap hasil belajar teknik dasar sepak takraw pada setiap kelompok gaya mengajar. Hal ini didukung oleh hasil penelitian Ianovici dan Weissblueth (2016), ketika peserta didik diberikan alat pembelajaran yang tepat, disesuaikan dengan tingkat individu dan kemampuan motorik mereka, mereka akan secara optimal meningkatkan prestasi dan kinerja motorik mereka.

Secara keseluruhan temuan dari hasil penelitian ini telah ditemukan bahwa baik motor ability maupun gaya mengajar, keduanya merupakan variabel penting dalam upaya meningkatkan hasil belajar teknik dasar sepak takraw mahasiswa Penjaskesrek Universitas Islam Riau. Kedua variabel tersebut satu sama lain saling mendukung dalam upaya mencapai hasil belajar yang optimal. Apabila motor ability berfungsi sebagai faktor internal yang membantu mendorong, mengarahkan dan menggerakkan perilaku belajar mahasiswa untuk meraih hasil belajar teknik dasar sepak takraw seoptimal mungkin. Maka gaya mengajar merupakan faktor eksternal yang sangat potensial menyokong hasil belajar teknik dasar yang setinggi-tingginya. Artinya, bahwa gaya mengajar latihan dan inklusi akan lebih baik diterapkan dengan mempertimbangkan motor ability yang dimiliki oleh mahasiswa untuk hasil belajar teknik dasar sepak takraw yang optimal.

\section{KESIMPULAN}

Kesimpulan penelitian ini sesuai dengan tujuan dan hasil penelitian, yaitu (1) Ada perbedaan pengaruh hasil belajar kelompok gaya mengajar latihan dan kelompok gaya mengajar inklusi terhadap hasil belajar teknik dasar sepak takraw pada mahasiswa Penjaskesrek Universitas Islam Riau yang memiliki motor ability tinggi, yang mana perolehan nilai hasil belajar teknik dasar sepak takraw pada mahasiswa yang memiliki motor ability tinggi kelompok gaya mengajar latihan memiliki hasil belajar yang lebih baik dari pada kelompok gaya mengajar inklusi. Disimpulkan bagi mahasiswa yang memiliki motor ability tinggi, gaya mengajar latihan lebih baik digunakan dan juga memiliki pengaruh yang lebih baik dari pada gaya mengajar inklusi untuk 
meningkatkan hasil belajar teknik dasar sepak takraw. (2) Ada perbedaan pengaruh hasil belajar kelompok gaya mengajar latihan dan kelompok gaya mengajar inklusi terhadap hasil belajar teknik dasar sepak takraw pada mahasiswa Penjaskesrek Universitas Islam Riau yang memiliki motor ability rendah, yang mana perolehan nilai hasil belajar teknik dasar sepak takraw pada mahasiswa yang memiliki motor ability rendah kelompok gaya mengajar latihan memiliki hasil belajar yang kurang baik dari pada kelompok gaya mengajar inklusi. Disimpulkan bagi mahasiswa yang memiliki motor ability rendah, gaya mengajar inklusi lebih baik digunakan dan juga memiliki pengaruh yang lebih baik dari pada gaya mengajar latihan untuk meningkatkan hasil belajar teknik dasar sepak takraw. (3) adanya pengaruh interaksi antara gaya mengajar dan motor ability terhadap hasil belajar teknik dasar sepak takraw pada mahasiswa Penjaskesrek Universitas Islam Riau. Dari kesimpulan tersebut memberikan implikasi bahwa dalam merancang suatu program pembelajaran, khususnya dalam memilih gaya mengajar yang akan digunakan untuk meningkatkan hasil belajar teknik dasar sepak takraw, seorang guru atau dosen penting mempertimbangkan gaya mengajar yang cocok dan sesuai dalam usaha mencapai tujuan dari pembelajaran yang ingin dicapai. Pembelajaran akan tercapai apabila gaya mengajar yang digunakan sesuai dengan karakterisrik dari mahasiswa dan karakteristik dari materi yang akan diajarkan. Dalam hasil penelitian ini menunjukkan bahwa pemilihan penggunaan gaya mengajar latihan akan memiliki pengaruh yang baik terhadap hasil belajar teknik dasar sepak takraw untuk mahasiswa yang memiliki motor ability tinggi. Sebaliknya, bagi mahasiswa yang memilili motor ability rendah, gaya mengajar inklusi memiliki pengaruh yang lebih baik terhadap hasil belajar teknik dasar sepak takraw. Hasil Penelitian ini dapat dipertanggung jawapkan secara ilmiah.

\section{DAFTAR PUSTAKA}

Arman, G. P., Sulaiman, \& Rustiadi, T. (2013). Model Pengembangan Permainan Takraw Asik Dalam Pembelajaran Penjasorkes Bola Besar Pada Siswa Kelas V Sekolah Dasar. ACTIVE: Journal of Physical Education, Sport, Health and Recreations, 2(3), 248-252. https://doi.org/10.15294/active.v2i3.1052.

Battineli, T. (2007). Physique, Fitnes, And Performance. Unites States Amerika: CRS Press.

Byra, M. (2018). Teaching Spectrum-Style-Part 1. The Journal of the Health and Physical Education Council of the Alberta Teachers' Association, 49(1), 24-31.

Byra, M., Sanchez, B., \& Wallhead, T. (2014). Behaviors Of Students And Teachers In The Command, Practice, And Inclusion Styles Of Teaching: Instruction, Feedback, And Activity Level. European Physical Education Review, 20(1), 3-19. https://doi.org/10.1177/1356336X13495999

Chatoupis, C. (2005). Effects of Practice And Inclusion Styles On Perceived Athletic Competence Of Greek Primary School Children. Studies in Physical Culture and Tourism, 12(1), 47-57. 
Chatoupis, C., \& Vagenas, G. (2018). Effectiveness of the Practice Style and Reciprocal Style of Teaching: A Meta-Analysis. The Physical Educator, 75(2), 175-194. https://doi.org/10.18666/tpe-2018-v75-i2-7920

Čoh, M., Golubović, D. J., \& Bratić, M. (2004). Motor Learning In Sport. Physical Education and Sport, 2(1), 45-49. https://doi.org/10.1007/BF00303591

Fernández-Rivas, M., \& Espada-Mateos, M. (2019). The knowledge, continuing education and use of teaching styles in Physical Education teachers. Journal of Human Sport and Exercise, 14(1), 99-111. 10.14198/jhse.2019.141.08.

Hanif, A. S. (2015). Kepelatihan Dasar Sepaktakraw. Jakarta: Rajawali Perss.

Harsono. (2015). Kepelatihan Olahraga. Bandung: PT Raja Grafindo.

Hein, V., Ries, F., Pires, F., Caune, A., Emeljanovas, A., Ekler, J. H., \& Valantiniene, I. (2012). The relationship between teaching styles and motivation to teach among physical education teachers. Journal of Sports Science and Medicine, 11(1), 123130.

Helaprahara, D. (2018). Pengaruh Pelatihan Split Squat Jump dan Lateral Jump Over Barrier Terhadap Peningkatan Power Otot Tungkai dan Kemampuan Smash Bolavoli. Bravo's Jurnal, 5(4), 1-10.

Ianovici, E., \& Weissblueth, E. (2016). Effects of learning strategies, styles and skill level on closed and semi-open motor skills acquisition. Journal of Physical Education and Sport, 16(4), 1169-1176. https://doi.org/10.7752/jpes.2016.04187

Jaakkola, T., \& Anthony, W. (2011). Finnish Physical Education Teachers' SelfReported Use and Perceptions of Mosston and Ashworth's Teaching Styles. Journal of Teaching in Physical Education, 30(3). https://doi.org/10.1123/jtpe.30.3.248

Kadir. (2010). Statistik Untuk Penelitian Ilmu-Ilmu Sosial Dilengkapi Dengan Output Program SPSS. Jakarta: Rosemata Sampurna.

Kadir. (2015). Statistik Terapan, Konsep, Contoh dan Analisis Data Dengan Program SPSS/Lisrel Dalam Penelitian. Jakarta: Raja Grafindo Persada.

Kosni, N. A., Abdullah, M. R., Juahir, H., Musa, R. M., Maliki, A. B. H. M., MatRasid, S. M.,Eswaramoorthi, V. (2017). Determination Association Of Anthropometric And Performance Ability In Sepak Takraw Youth Athlete Using Unsupervised Multivariate. Journal of Fundamental and Applied Sciences, 9(2S), 505-520. https://doi.org/http://dx.doi.org/10.4314/jfas.v9i2s.33 
Kosni, N. A., Abdullah, M. R., Nazarudin, M. N., Musa, R. M., Maliki, A. B. H. M., Adnan, A., ... Juahir, H. (2018). A Comparative Analysis of Juggling Skill Between Sepak Raga and Bulu Ayam. Journal of Fundamental and Applied Sciences, 10(1S), 857-868. https://doi.org/http://dx.doi.org/10.4314/jfas.v10i1s.35

Mosston, M., \& Ashworth, S. (2008). Teaching Physical Education. New York: Mac Millan College Publishing Inc.

Morrow-Jr, J. R., Mood, D., Disch, J., \& Kang, M. (2015). Measurement and Evaluation in Human Performance, $5 E$. Human Kinetics.

Prasetyo, Y. E. (2013). Survei Penggunaan Gaya Mengajar Yang Digunakan Oleh Guru Penjas SD Negeri Se-Kecamatan Tulung Kabupaten Klaten. Skripsi: Prodi Pendidikan Guru Sekolah Dasar Penjas Pendidikan Olahraga Fakultas Ilmu Keolahragaan Universitas Negeri Yogyakarta.

Puspitorini, W., \& Tangkudung, J. A. P. (2016). The Effect of Visualization and Motor Ability To the Learning Outcomes Badminton Skills. Journal of Indonesian Physical Education and Sport, 2(1).

Saputra, H. A., Yarmani., Sugihartono, T., \& Defliato. (2018). Penerapan Variasi Modifikasi Bola Karet Untuk Meningktkan Keterampilan Servis Bawah Sepak Takraw. Kinestik: Jurnal Ilmiah Pendidikan Jasmani, 2(2), 215-225. https://doi.org/10.33369/jk.v2i2.8744.

Setiawan, R. A. B., \& Nopembri, S. (2013). Penggunaan Gaya Mengajar "Mosston" Oleh Guru Pendidikan Jasmani di SMA Se-Kota Yogyakarta. Jurnal Pendidikan Jasmani Indonesia, 9(1), 7-14. https://doi.org/10.21831/jpji.v9i1.3057.

Sigit, P. (2014). Upaya Meningkatkan Hasil Belajar Sepak Takraw Melalui Permainan Krawnis Pada Siswa Kelas V SDN 01 Depok Kecamatan Siwalan Kabupaten Pekalongan Tahun 2013. Journal of Physical Education, Sport, Health and Recreations, 3(4), 984-988. https://doi.org/10.15294/active.v3i4.3147.

Sugiyono. (2010). Metode Pendidikan Pendekatan Kuantitatif, Kualitatif dan R\&D. Bandung: Alfabeta.

Suprayitno. (2018). Hasil Belajar Sepak Sila Permainan Sepak Takraw (Studi Ekperimen tentang Pengaruh Gaya Mengajar Dan Kemampuan Motorik pada Mahasiswa PJKR FIK Unimed). Jurnal Ilmu Keolahragaan, 17(1), 58-68. https://doi.org/10.24114/jik.v17i1.9964.

Syah, H. (2010). Pengantar Umum Metodologi Penelitian Pendidikan. Yogyakarta: Printing Cemerlang.

Thomson, W. C. (2010). Styles of Teaching: Style B - The Practice Style. VAHPERD Journal, 31(2), 4-8. 
Verducci, F. R. (1989). Measurement Concep in Physical Education. St. Louis Missouri: Mosby Company.

Widodo, N. R., \& Sudarso. (2018). Pengaruh Penerapan Modifikasi Permainan Sepak Takraw Sepak Sila Terhadap Motivasi Belajar Siswa Dalam Pembelajaran Pendidikan Jasmani, Olahraga dan Kesehatan (Studi pada Siswa Kelas V SDN Perak Utara 1/58 Surabaya ). Jurnal Pendidikan Olahraga dan Kesehatan, 6(1), 78-82. 